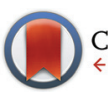

CrossMark \&lick for updates

Cite this: Polym. Chem., 2015, 6 , 2312

Received 25th November 2014, Accepted 24th January 2015

DOI: 10.1039/c4py01631a www.rsc.org/polymers

\title{
Effect of molecular weight on the properties and organic solar cell device performance of a donor- acceptor conjugated polymer $\uparrow$
}

\author{
Zeyun Xiao, ${ }^{a}$ Kuan Sun, ${ }^{a}$ Jegadesan Subbiah, ${ }^{a}$ Tianshi Qin, ${ }^{b}$ Shirong Lu, \\ Balaji Purushothaman, ${ }^{a}$ David J. Jones, ${ }^{a}$ Andrew B. Holmes ${ }^{a, b}$ and \\ Wallace W. H. Wong*a
}

\begin{abstract}
Donor-acceptor conjugated polymers with 2-(2-ethylhexyl)-3-hexyl thienyl substituted benzo[1,2-b:4,5$\left.b^{\prime}\right]$ dithiophene (BDT) as donor building block and 5,6-difluorobenzo[c] [1,2,5]thiadiazole as acceptor building block have been synthesized by Stille coupling polymerization. The polymerization conditions were optimized to achieve high molecular weight polymers (number-average molecular weight, $M_{n}$, up to $139 \mathrm{~kg} \mathrm{~mol}^{-1}$ ). The molecular weight dependent polymer properties were studied and compared. Photovoltaic applications of the polymers in bulk heterojunction $(\mathrm{BHJ})$ solar cells revealed that the power conversion efficiency increased significantly (from $0.9 \%$ to $4.1 \%$ ) as the $M_{\mathrm{n}}$ increased from $10 \mathrm{~kg} \mathrm{~mol}^{-1}$ to $73 \mathrm{~kg} \mathrm{~mol}{ }^{-1}$ while further increase of the molecular weight had less influence on the solar cell performance.
\end{abstract}

\section{Introduction}

Stille coupling polymerization is one of the most widely used polymerization methods for the synthesis of conjugated polymers which are the basis of modern organic electronics. ${ }^{1-7}$ The advantage of using Stille coupling polymerization lies in its compatibility with various functional groups, which have made the syntheses of numerous functional polymers possible. ${ }^{4}$ However, it is often difficult to achieve high molecular weight polymers as a result of a combination of factors including monomer purity and stability, degree of conversion and rate of reaction. ${ }^{4}$ On the other hand, studies on the influence of molecular weight on polymer electronic properties repeatedly showed that bulk heterojunction (BHJ) solar cell performance improved significantly as the molecular weight of the conjugated polymers increased. ${ }^{8-11}$ For example, BHJ solar

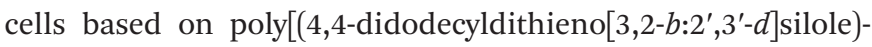
2,6-diyl-alt-(2,1,3-benzothiadiazole)-4,7-diyl] active layer showed increased short-circuit current density $\left(J_{\mathrm{sc}}\right)$ from 4.2 to $17.3 \mathrm{~mA} \mathrm{~cm}{ }^{-2}$ and increased fill factor (FF) from 0.35 to 0.61

\footnotetext{
${ }^{a}$ School of Chemistry, Bio21 Institute, the University of Melbourne, 30 Flemington Road, Parkville, Victoria 3010, Australia. E-mail: wwhwong@unimelb.edu.au; Fax: +61 3 83442384; Tel: +61 383442371

${ }^{b}$ CSIRO Materials Science and Engineering, Private Bag 10, Clayton South, Victoria 3169, Australia

$\dagger$ Electronic supplementary information (ESI) available. See DOI: 10.1039/ c4py01631a
}

as the $M_{\mathrm{n}}$ increased from 7 to $34 \mathrm{~kg} \mathrm{~mol}^{-1} .{ }^{9}$ These changes resulted in nearly a five-fold enhancement in the power conversion efficiency (PCE) from 1.2 to $5.9 \%$. BHJ solar cells using polymer fractions with number average molecular weight, $M_{\mathrm{n}}$, of 10,18 , and $31 \mathrm{~kg} \mathrm{~mol}^{-1}$ exhibited PCE of $3.0 \%, 5.2 \%$, and $7.5 \%$, respectively, displaying a nearly linear increase in solar cell performance with increasing molecular weight. ${ }^{10}$ It was thought that polymers with high molecular weight exhibited more isotropic films and enhanced interconnectivity, potentially leading to larger values for charge-carrier mobility. ${ }^{12}$ The enhanced performance in $\mathrm{BHJ}$ solar cells with increasing polymer molecular weight was also attributed to the more favoured active layer morphology and decreased series resistance. ${ }^{8,10}$ However, in the aforementioned studies, the molecular weight ranges were quite limited (with the highest $M_{\mathrm{n}}$ around only $30 \mathrm{~kg} \mathrm{~mol}^{-1}$ ). Questions may be raised: "Can the solar cell performance increase linearly with the molecular weight, or there is a limit beyond which the performance saturates?" To address these questions, conjugated polymers of extremely high molecular weight need to be synthesized. In this work, we optimized the Stille coupling polymerization conditions to get extremely high molecular weight donoracceptor conjugated polymers and studied their molecularweight-dependent $\mathrm{BHJ}$ solar cell performances.

Benzo[1,2-b:4,5- $\left.b^{\prime}\right]$ dithiophene (BDT) based conjugated polymers are frequently used in $\mathrm{BHJ}$ solar cells as donor materials. ${ }^{13-25}$ By replacing the substituent of 2-ethylhexyloxy group with 2-(2-ethylhexyl)thienyl group, the PCE increased 


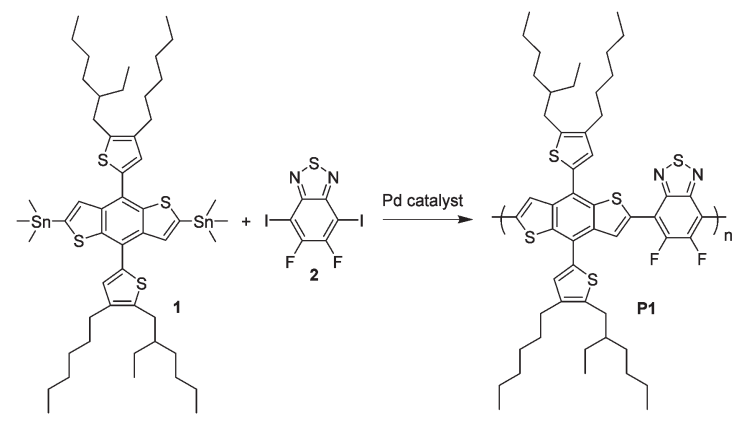

Fig. 1 Chemical structures of compound 1 and 2 and the Stille polymerization for conjugated polymer P1.

from $6.43 \%$ to $7.59 \% .^{26}$ The introduction of two alkyl chains on the same thiophene ring were found to enhance the solubility and processability of the resulting polymers. ${ }^{15,27}$

In this study, we use 4,8-di(2-(2-ethylhexyl)-3-hexyl-thiophen-5-yl)-benzo[1,2- $\left.b: 4,5-b^{\prime}\right]$ dithiophene (DTBDT) as the donor building block and 5,6-difluoro-2,1,3-benzothiadiazole (DFBT) as the acceptor building block for the polymer (Fig. 1) with the aim of getting deep-lying highest occupied molecular orbital (HOMO) energy level and thus high open circuit voltage $\left(V_{\mathrm{oc}}\right)$ in the $\mathrm{BHJ}$ solar cells. ${ }^{28-33}$ The bis(trimethylstannyl)DTBDT monomer (compound 1) was coupled with diiodoDFBT monomer (compound 2) using a variety of Stille polycondensation conditions to give poly[(4,8-di(2-(2-ethylhexyl)-3hexylthiophen-5-yl)-benzo[1,2- $\left.b: 4,5-b^{\prime}\right]$ dithio-phene)-2,6-diylalt-(5,6-difluoro-2,1,3-benzothiadiazole)-4,7-diyl]

samples with different molecular weight ranges.

\section{Synthesis and characterization}

\section{Synthesis of the polymer by Stille coupling polymerization}

To ensure monomer purity for the Stille polycondensation, compound 1 was recrystallized from dichloromethane and isopropanol at $5{ }^{\circ} \mathrm{C}$ and compound 2 was recrystallized from dichloromethane. The Stille coupling polymerization was first conducted with a widely-used catalyst, $\mathrm{Pd}\left(\mathrm{PPh}_{3}\right)_{4}$, and toluene/ DMF as the solvent. Under this condition, most of the polymer material was isolated by Soxhlet extraction with dichloro- methane. The yield of the chloroform extract was low (13\%, see Table 1) and the $M_{\mathrm{n}}$ was $32 \mathrm{~kg} \mathrm{~mol}^{-1}$. Microwave heating was used to try and increase the molecular weight and the yield of the chloroform fraction but there was little improvement. A more active catalyst system $\mathrm{Pd}_{2}(\mathrm{dba})_{3} / \mathrm{P}(o \text {-tolyl })_{3}$ was then used along with chlorobenzene as solvent to better solvate the sparingly soluble conjugated polymers. ${ }^{34,35}$ This condition was found to be particularly efficient in increasing the molecular weight and the chloroform fraction of the polymer. Polymer with $M_{\mathrm{n}}$ of $72.9 \mathrm{~kg} \mathrm{~mol}^{-1}$ was obtained in 77\% yield. Increasing the monomer concentration from $0.1 \mathrm{M}$ to $0.25 \mathrm{M}$ further increased the $M_{\mathrm{n}}$ to $138.9 \mathrm{~kg} \mathrm{~mol}^{-1}$ (see ESI $\dagger$ for GPC traces). Other phosphine ligands were also tested, including $\mathrm{P}(o \text {-anisolyl })_{3}$, but none worked as well as the $\mathrm{P}(o$ tolyl $)_{3}$ ligand. ${ }^{4,36,37}$

Five samples of polymer P1, whose chemical structure was shown in Fig. 1, were collected and their optoelectronic and photovoltaic properties were studied. The molecular weight range of the polymer samples is shown in Table 2. Sample P19.6k ( $M_{\mathrm{n}} 9.6 \mathrm{~kg} \mathrm{~mol}^{-1}$, PDI 1.57) was obtained from dichloromethane extract of the reaction described in entry 2 of Table 1 while P1-17.1k ( $M_{\mathrm{n}} 17.1 \mathrm{~kg} \mathrm{~mol}^{-1}$, PDI 1.50) was obtained from dichloromethane extract and P1-32.0k $\left(M_{\mathrm{n}} 32.0 \mathrm{~kg} \mathrm{~mol}^{-1}\right.$, PDI 1.70) was obtained from chloroform extract of the reaction described in entry 1 of Table 1 . Samples P1-72.9k $\left(M_{\mathrm{n}} 72.9 \mathrm{~kg}\right.$ $\mathrm{mol}^{-1}$, PDI 3.51) and P1-138.9k ( $M_{\mathrm{n}} 138.9 \mathrm{~kg} \mathrm{~mol}^{-1}$, PDI 5.33) were extracted with chloroform from the reactions described in entries 3 and 4 of Table 1 respectively. The five samples of polymer P1 showed similar FT-IR spectra indicating the same chemical composition (Fig. S6†). However, as the molecular weight increased, the ${ }^{1} \mathrm{H}$ NMR spectra lost some fine structures and the peaks became broadened owing to the increased number of repeating units (Fig. S7 $\dagger$ ). Differential scanning calorimetry (DSC) of the polymers showed no thermal transitions for any of the polymers between $25^{\circ} \mathrm{C}$ and $300{ }^{\circ} \mathrm{C}$ (Fig. S8†).

\section{Characterization of optoelectronic properties}

The UV-vis absorption spectra of the five fractions of P1 in chloroform solutions and in films are shown in Fig. 2. In solution, as the $M_{\mathrm{n}}$ increased from $9.6 \mathrm{~kg} \mathrm{~mol}^{-1}$ to $72.9 \mathrm{~kg} \mathrm{~mol}{ }^{-1}$, the absorption maximum $\left(\lambda_{\max }\right)$ increased from $651 \mathrm{~nm}$ to

Table 1 The Stille coupling polymerization conditions and the resulting polymer molecular weights of $\mathrm{P}^{a}$

\begin{tabular}{|c|c|c|c|c|c|c|c|}
\hline Entry & Catalyst $^{b}$ & Temperature $^{c}$ & $\begin{array}{l}\text { Monomer } \\
\text { concentration }\end{array}$ & Solvent & Yield & $\begin{array}{l}\text { Chloroform } \\
\text { fraction } M_{\mathrm{n}} \\
\left(\mathrm{kg} \mathrm{mol}{ }^{-1}\right)\end{array}$ & PDI \\
\hline 1 & $\operatorname{Pd}\left(\mathrm{PPh}_{3}\right)_{4}$ & $120^{\circ} \mathrm{C}$ & $0.1 \mathrm{M}$ & Toluene-DMF $5: 1$ & $13 \%$ & 32.0 & 1.70 \\
\hline 2 & $\mathrm{Pd}\left(\mathrm{PPh}_{3}\right)_{4}$ & $150-170{ }^{\circ} \mathrm{C}$ & $0.1 \mathrm{M}$ & Xylene & $15 \%$ & 31.5 & 1.21 \\
\hline 3 & $\mathrm{Pd}_{2}(\mathrm{dba})_{3}, \mathrm{P}(o \text {-tolyl })_{3}$ & $130^{\circ} \mathrm{C}$ & $0.1 \mathrm{M}$ & Chlorobenzene & $77 \%$ & $72.9^{d}$ & $3.51^{d}$ \\
\hline 4 & $\mathrm{Pd}_{2}(\mathrm{dba})_{3}, \mathrm{P}(o \text {-tolyl })_{3}$ & $130^{\circ} \mathrm{C}$ & $0.25 \mathrm{M}$ & Chlorobenzene & $64 \%$ & $138.9^{d}$ & $5.33^{d}$ \\
\hline 5 & $\mathrm{Pd}_{2}(\mathrm{dba})_{3}, \mathrm{P}(o \text {-anisolyl })_{3}$ & $130{ }^{\circ} \mathrm{C}$ & $0.1 \mathrm{M}$ & Chlorobenzene & & Trace & \\
\hline
\end{tabular}

${ }^{a}$ All the reactions were run on $0.15 \mathrm{mmol}$ scale and the polymers were extracted successively with methanol, acetone, petroleum spirits, dichloromethane and chloroform. ${ }^{b}$ The catalyst loadings were $5 \% \mathrm{~mol} \mathrm{Pd}\left(\mathrm{PPh}_{3}\right)_{4}$ for entry 1 and $2,1.5 \mathrm{~mol}_{0} \mathrm{Pd}_{2}\left(\mathrm{dba}_{3}\right.$ and $9 \mathrm{~mol} \% \mathrm{P}(o \text {-tolyl })_{3}$ for entries 3 and $4,1.5 \mathrm{~mol}_{0} \mathrm{Pd}_{2}(\mathrm{dba})_{3}$ and $9 \mathrm{~mol} \% \mathrm{P}(o \text {-anisolyl })_{3}$ for entry $5 .{ }^{c}$ Entry 2 was heated with microwave. ${ }^{d}$ Molecular weight obtained by using high-temperature GPC at $120^{\circ} \mathrm{C}$ with $1,2,4$-trichlorobenzene as eluent. 
Table 2 The optical properties and electronic energy levels of the polymers

\begin{tabular}{|c|c|c|c|c|c|c|c|}
\hline Polymer & $M_{\mathrm{n}}{ }^{a}\left(\mathrm{~kg} \mathrm{~mol}^{-1}\right)$ & $\mathrm{PDI}^{a}$ & $\begin{array}{l}\text { UV-vis } \lambda_{\max }{ }^{b} \\
(\mathrm{~nm})\end{array}$ & $\begin{array}{l}\text { UV-vis } \lambda_{\text {onset }}{ }^{c} \\
(\mathrm{~nm})\end{array}$ & $\begin{array}{l}\text { Optical gap } \\
(\mathrm{eV})\end{array}$ & $\begin{array}{l}E_{\mathrm{HOMO}}{ }^{e} \\
(\mathrm{eV})\end{array}$ & $\begin{array}{l}E_{\text {LUMO }}{ }^{f} \\
(\mathrm{eV})\end{array}$ \\
\hline P1-9.6k & $9.6(13.4)$ & $1.57(1.53)$ & 651 (656) & 705 (723) & 1.72 & -5.53 & -3.81 \\
\hline P1-32.0k & $32.0(19.1)$ & $1.70(4.85)$ & $656(665)$ & 707 (735) & 1.69 & -5.52 & -3.83 \\
\hline P1-72.9k & $(72.9)$ & $(3.51)$ & $658(670)$ & 710 (741) & 1.67 & -5.52 & -3.85 \\
\hline P1-138.9k & (138.9) & (5.33) & $658(670)$ & $710(741)$ & 1.67 & -5.49 & -3.82 \\
\hline
\end{tabular}

${ }^{a}$ HT-GPC data in brackets. ${ }^{b}$ UV-vis absorption maxima in chloroform solution and as thin films in bracket. ${ }^{c}$ UV-vis onset absorption in chloroform solution and as thin films in bracket. ${ }^{d}$ Calculated from thin film absorption onset. ${ }^{e}$ Measured using CV. ${ }^{f}$ Calculated from the HOMO energy level and the optical HOMO-LUMO gap.
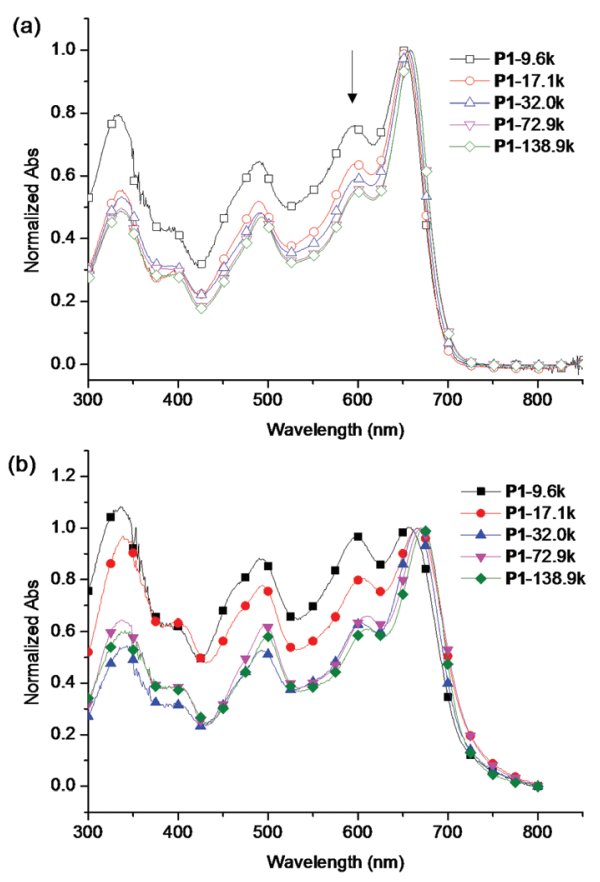

Fig. 2 UV-Vis absorption spectra of the five polymer fractions in (a) chloroform and (b) solid film. The spectra were normalized at the absorption maximum.

$658 \mathrm{~nm}$ and the onset absorption $\left(\lambda_{\text {onset }}\right)$ increased from $705 \mathrm{~nm}$ to $710 \mathrm{~nm}$ due to the increased conjugation length. However, the $\lambda_{\max }$ and the $\lambda_{\text {onset }}$ of polymer samples with $M_{\mathrm{n}}$ $72.9 \mathrm{~kg} \mathrm{~mol}^{-1}$ and $138.9 \mathrm{~kg} \mathrm{~mol}{ }^{-1}$ were the same, implying that an effective conjugated length for the HOMO-LUMO energy gap was already reached at the $M_{\mathrm{n}}$ of $72.9 \mathrm{~kg} \mathrm{~mol}{ }^{-1}$. $^{9}$ The relative intensity of the main absorption to the shoulder peak at $594 \mathrm{~nm}$ also increased possibly due to the increased percentage of large molecular weight polymers. This phenomenon was also observed in other polymer systems. ${ }^{9,38}$ The absorption of different fractions of $\mathbf{P 1}$ in solid films showed similar trends as in the chloroform solution. The solid film $\lambda_{\text {max }}$ increased from $656 \mathrm{~nm}$ to $670 \mathrm{~nm}$ and the $\lambda_{\text {onset }}$ increased from $723 \mathrm{~nm}$ to $741 \mathrm{~nm}$, resulting in a reduction of optical energy gap from $1.72 \mathrm{eV}$ to $1.67 \mathrm{eV}$ as the molecular weight increased. The polymers showed solution emission maxima around $700 \mathrm{~nm}$ and slightly red-shifted emission maxima of $714 \mathrm{~nm}$ in the solid films (Fig. S9†).
The HOMO energy levels of the five polymer fractions were estimated by cyclic voltammetry measurements (see ESI for experimental details, Fig. S10†). Owing to the incorporated 5,6-difluoro-2,1,3-benzothiadiazole acceptor moiety, all the polymers possessed deep-lying HOMO energy levels (around $-5.5 \mathrm{eV}$ ), which is promising for achieving high $V_{\mathrm{oc}}$ in organic photovoltaic cells. ${ }^{39-41}$ It was also observed that the polymer fractions showed a slight HOMO level increase as the molecular weight increased (Table 2). The lowest molecular weight polymer P1-9.6k exhibited a HOMO level of $-5.53 \mathrm{eV}$ while the highest molecular weight polymer $\mathbf{P 1}-138.9 \mathrm{k}$ displayed a HOMO level of $-5.49 \mathrm{eV}$.

\section{$\mathrm{BHJ}$ solar cell fabrication and characterization}

The photovoltaic properties of the five polymer fractions were investigated in $\mathrm{BHJ}$ solar cell devices. A schematic diagram of the solar cells with inverted device architecture [ITO/ZnO/ active layer $/ \mathrm{MoO}_{3} / \mathrm{Ag}$ ] is shown in the ESI. $\dagger$ 1,2-Dichlorobenzene $(o \mathrm{DCB})$ was chosen as the processing solvent owing to its good solvent properties and low evaporation rates. An optimized blend ratio of $1: 2$ between polymer and $\mathrm{PC}_{71} \mathrm{BM}$ acceptor was used for spin coating the active layer. The blend film UV-vis absorption spectra showed similar profiles for samples containing different molecular weight polymers (Fig. S11†). The films containing higher molecular weight material showed slightly enhanced absorption at the longer wavelength absorption band (670 nm). This is consistent with the absorption spectrum of the neat polymer films (Fig. 2b).

The devices were studied under the illumination of AM 1.5 $\mathrm{G}, 100 \mathrm{~mW} \mathrm{~cm}^{-2}$. The current density-voltage $(J-V)$ curves of the polymer $/ \mathrm{PC}_{71} \mathrm{BM}$ devices are displayed in Fig. $3 \mathrm{a}$ and the photovoltaic performance (average of 10 devices) is listed in Table 3. The open circuit voltage $\left(V_{\mathrm{oc}}\right)$ and the fill factor $(\mathrm{FF})$ of the $\mathrm{BHJ}$ solar cells were essentially the same for all devices containing the five different molecular weight polymer samples (Fig. 3c and d). In great contrast, the short circuit current density $\left(J_{\mathrm{sc}}\right)$ increased significantly from $2.0 \mathrm{~mA} \mathrm{~cm}{ }^{-2}$ to $9.9 \mathrm{~mA} \mathrm{~cm}{ }^{-2}$ as the $M_{\mathrm{n}}$ increased from $9.6 \mathrm{~kg} \mathrm{~mol}^{-1}$ to $72.9 \mathrm{~kg} \mathrm{~mol}{ }^{-1}$ (Fig. 3c). It was found that further increase of the molecular weight did not increase the $J_{\text {sc }}$ further, instead 

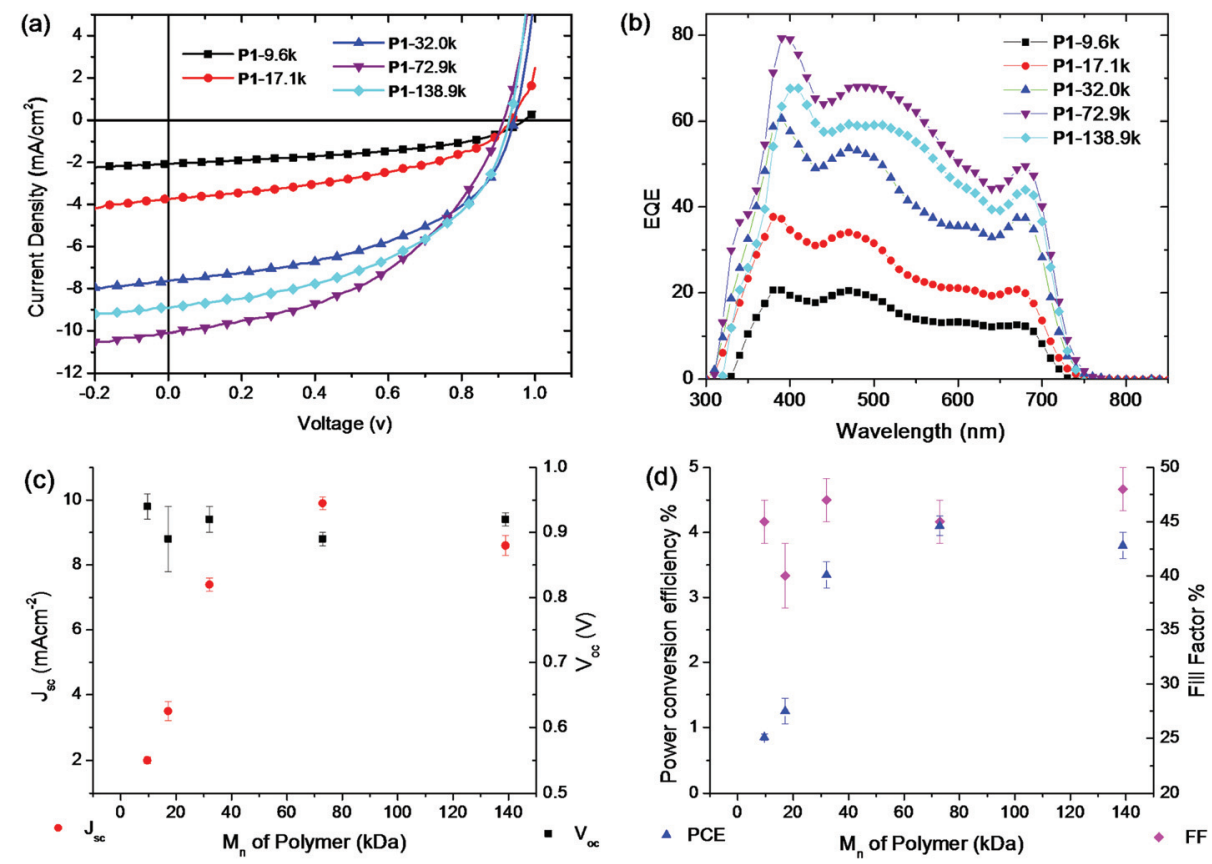

Fig. 3 (a) $J-V$ characteristics of photovoltaic devices fabricated with different molecular weight $\mathrm{P} 1 / \mathrm{PC} \mathrm{C}_{71} \mathrm{BM}$ under $\mathrm{AM} 1.5 \mathrm{G}$ irradiation (100 mW $\mathrm{cm}^{-2}$ ). (b) EQE curves of the BHJ solar cells fabricated under the same optimized conditions as used for the $J-V$ measurements. (c) $M_{n}$ of polymer plotted against $J_{\mathrm{sc}}$ and $V_{\mathrm{oc}}$ and (d) $M_{\mathrm{n}}$ of polymer plotted against FF and PCE.

Table 3 Photovoltaic properties of the BHJ solar cells based on the polymer fractions and the hole mobility of the blend films ${ }^{a}$

\begin{tabular}{llllll}
\hline & \multicolumn{3}{c}{$J_{\text {sc }}$} \\
Polymer $^{a}$ & $V_{\text {oc }}(\mathrm{V})$ & $\left(\mathrm{mA} \mathrm{cm}{ }^{-2}\right)$ & FF (\%) & PCE (\%) & $\begin{array}{l}\mu_{\mathrm{h}}{ }^{b} \\
\left(\mathrm{~cm}^{2} \mathrm{~V}^{-1} \mathrm{~s}^{-1}\right)\end{array}$ \\
\hline P1-9.6k & $0.94 \pm 0.02$ & $2.0 \pm 0.1$ & $45 \pm 2$ & $0.85 \pm 0.05$ & $2.5 \times 10^{-6}$ \\
P1-17.1k & $0.89 \pm 0.05$ & $3.5 \pm 0.3$ & $40 \pm 3$ & $1.25 \pm 0.20$ & $5.4 \times 10^{-6}$ \\
P1-32.0k & $0.92 \pm 0.02$ & $7.4 \pm 0.2$ & $47 \pm 2$ & $3.35 \pm 0.20$ & $2.6 \times 10^{-5}$ \\
P1-72.9k & $0.89 \pm 0.01$ & $9.9 \pm 0.2$ & $45 \pm 2$ & $4.10 \pm 0.15$ & $3.7 \times 10^{-5}$ \\
P1-138.9k & $0.92 \pm 0.01$ & $8.6 \pm 0.3$ & $48 \pm 2$ & $3.80 \pm 0.20$ & $3.8 \times 10^{-5}$
\end{tabular}

${ }^{a}$ The weight ratio of $\mathbf{P 1} / \mathrm{PC}_{71} \mathrm{BM}$ was $1: 2$ and the average values (10 devices) are shown with standard deviation. ${ }^{b}$ Measured by using the space-charge-limited current (SCLC) method (see ESI†).

the P1-138.9k even showed a slightly decreased $J_{\mathrm{sc}}$ of $8.6 \mathrm{~mA}$ $\mathrm{cm}^{-2}$. As a result, the overall power conversion efficiency (PCE) increased from $0.85 \%$ to $4.10 \%$ as the $M_{\mathrm{n}}$ increased from $9.6 \mathrm{~kg} \mathrm{~mol}{ }^{-1}$ to $72.9 \mathrm{~kg} \mathrm{~mol}{ }^{-1}$ and the device containing P1-138.9k showed lower PCE than the devices containing P1-72.9k. Literature reports have shown a similar increase of PCE in the low molecular weight range $\left(M_{\mathrm{n}}\right.$ up to about $30 \mathrm{~kg}$ $\left.\mathrm{mol}^{-1}\right) .{ }^{9,10,42}$ However the higher molecular weight range has been seldom discussed with only a few examples for donoracceptor polymers in recent literature. ${ }^{43,44}$ Our results showed that the PCE reached a peak value of $4.10 \%$ as the $M_{\mathrm{n}}$ increased to $72.9 \mathrm{~kg} \mathrm{~mol}{ }^{-1}$. These results indicated that a maximum PCE could be reached at a certain molecular weight for a specific polymer and further increase of the molecular weight might not result in further improvements in device performance. It is important to note that device fabrication optimisation, including adjusting substrate temperature and spin coating speed, was attempted on the high molecular weight material but failed to give improvements in device performance. ${ }^{45}$ It is also interesting to note that an analogous polymer system ${ }^{18}$ with $M_{\mathrm{n}}$ of $22.6 \mathrm{~kg} \mathrm{~mol}^{-1}$ gave very similar device performance to that of P1-17.1k at around 1\% PCE.

The external quantum efficiencies (EQEs) of the solar cell devices were also studied. Fig. 3b shows the EQE curves of the solar cells fabricated under the same optimized conditions as those used for the $J-V$ measurements. Clearly, the EQE values for devices containing the high molecular weight polymers are higher than those of low molecular weight polymer based solar cells, which agree with the $J-V$ measurements. The EQE curves of the $\mathrm{BHJ}$ solar cells made from the polymers of higher molecular weights showed significant improvement across the whole spectral response region, indicating that the enhancement in $J_{\mathrm{sc}}$ was mainly due to more efficient exciton dissociation and charge collection from both the polymer and the $\mathrm{PC}_{71} \mathrm{BM}$ domains. ${ }^{10}$

To gain further insight into the PCE change as a result of the different polymer molecular weights, the hole mobility was derived using the space-charge-limited current (SCLC) method, with a hole-only device configuration of ITO/PEDOT: $\mathrm{PSS} /$ polymer: $\mathrm{PC}_{71} \mathrm{BM} / \mathrm{Au}$. The mobility data in Table 3 clearly showed that the hole mobility was enhanced when the molecular weight increased, which is consistent with the improved $J_{\text {sc }}$ and photovoltaic performance of the $\mathrm{BHJ}$ solar cells. ${ }^{26}$ In particular, the hole mobility increased 10 times as the $M_{\mathrm{n}}$ increased from $9.6 \mathrm{~kg} \mathrm{~mol}{ }^{-1}$ to $32.0 \mathrm{~kg} \mathrm{~mol}{ }^{-1}$, while from $32.0 \mathrm{~kg} \mathrm{~mol}{ }^{-1}$ to $138.9 \mathrm{~kg} \mathrm{~mol}{ }^{-1}$, the hole mobility only 
increased by $46 \%$. Furthermore, the P1-72.9k and P1-138.9k polymers displayed very similar hole mobility of $3.7 \times 10^{-5}$ and $3.8 \times 10^{-5} \mathrm{~cm}^{2} \mathrm{~V}^{-1} \mathrm{~s}^{-1}$, respectively. These results suggested that the hole mobility was not linearly dependent on the molecular weight, especially in the high molecular weight range. A 'saturated' hole mobility can be reached at a certain molecular weight for a specific polymer. Recent studies revealed that low molecular weight conjugated polymers can form solid films with crystalline domains surrounded by a disordered phase, but these domains remain largely disconnected from each other, resulting in charge-transport bottlenecks at the amorphous grain boundaries. ${ }^{46,47}$ In contrast, in high molecular weight conjugated polymers, even though the long-range order in the crystalline domains is compromised, the interconnectivity is greatly improved as a result of the rigid and sufficiently long chains that link the domains, like bridges that link islands which can improve the mobility. ${ }^{46,47}$

\section{Morphological studies}

To understand the hole mobility change and to study the morphology of the blend films of $\mathbf{P 1}$ fractions and $\mathrm{PC}_{71} \mathrm{BM}$, tapping mode atomic force microscopy (AFM) studies were conducted (Fig. 4). The P1/PC ${ }_{71} \mathrm{BM}$ blend films with polymers of different molecular weight exhibited different topographies, and the root-mean-square roughness $\left(R_{\mathrm{rms}}\right)$ increased as the molecular weight increased $\left(R_{\mathrm{rms}}: \mathbf{P 1}-9.6 \mathrm{k}, 1.3 \mathrm{~nm}\right.$; P1-17.1k, $2.9 \mathrm{~nm}$; P1-32.0k, $4.1 \mathrm{~nm}$; P1-72.9k, 8.4 nm; P1-138.9k, $9.5 \mathrm{~nm}$ ). Since the polymer length was in the nanometer scale, random orientation of the polymer backbone could lead to the increase in roughness. The difference in the phase images was even evident. The blend film prepared with the lowest molecular weight polymer, P1-9.6k and $\mathrm{PC}_{71} \mathrm{BM}$, showed a clear, phase-separated morphology with finer, fibrous nanoscale domains (Fig. 4f), while this feature was gradually lost as the molecular weight increased (Fig. $4 \mathrm{~g}-\mathrm{j}$ ). This could be related to polymer chain conformation and inter-chain interactions of P1. As the polymer molecular weight increased, its solubility decreased and it tended to form aggregates. ${ }^{48}$ As a result, the domain size became larger. It should be noted that the domain sizes were still comparable to the exciton diffusion length, so the mobility as well as the solar cell performance were not diminished. ${ }^{10,42}$

Meanwhile, less discontinuous phase separation was observed when the $M_{\mathrm{n}}$ increased to $32.0 \mathrm{~kg} \mathrm{~mol}^{-1}$. The blend films of the P1-72.9k and P1-138.9k showed similar phase images with extended polymer chains promoting interconnectivity between neighbouring fiber domains, reducing grain boundaries and thus facilitating charge carrier transport. ${ }^{49}$ This result was also consistent with the similar hole mobility of P1-72.9k and P1-138.9k obtained by SCLC measurements.

\section{Conclusions}

The influence of the molecular weight on the properties of the donor-acceptor conjugated polymers is a very important consideration when comparing materials. In this work, we optimized the Stille coupling polymerization conditions to synthesize donor-acceptor conjugated polymers of extremely high molecular weight. Our results made possible the comparison of conjugated polymer properties in a large range of molecular weights. In our series of polymers, the absorption maximum red shifted from $651 \mathrm{~nm}$ to $658 \mathrm{~nm}$ as the $M_{\mathrm{n}}$ increased from $9.6 \mathrm{~kg} \mathrm{~mol}{ }^{-1}$ to $72.9 \mathrm{~kg} \mathrm{~mol}^{-1}$ while further increase of the molecular weight did not cause red-shift of the absorption maximum. This phenomenon indicated that a maximum conjugation length was achieved at a certain molecular weight. The BHJ solar cell efficiency increased drastically in the low molecular weight range (from $9.6 \mathrm{~kg} \mathrm{~mol}^{-1}$ to $32.0 \mathrm{~kg} \mathrm{~mol}{ }^{-1}$ ) while in high molecular weight range, the enhancement was less significant. A peak PCE value of $4.25 \%$ was achieved at a $M_{\mathrm{n}}$ of $72.9 \mathrm{~kg} \mathrm{~mol}^{-1}$. The SCLC measurement suggested a ten-fold increase of the hole mobility as the $M_{\mathrm{n}}$ increased from $9.6 \mathrm{~kg} \mathrm{~mol} \mathrm{~m}^{-1}$ to $32.0 \mathrm{~kg} \mathrm{~mol}{ }^{-1}$. However, further increase the $M_{\mathrm{n}}$ to $138.9 \mathrm{~kg} \mathrm{~mol} \mathrm{~m}^{-1}$ only increase the hole mobility by $46 \%$. All in all, the results indicated that there
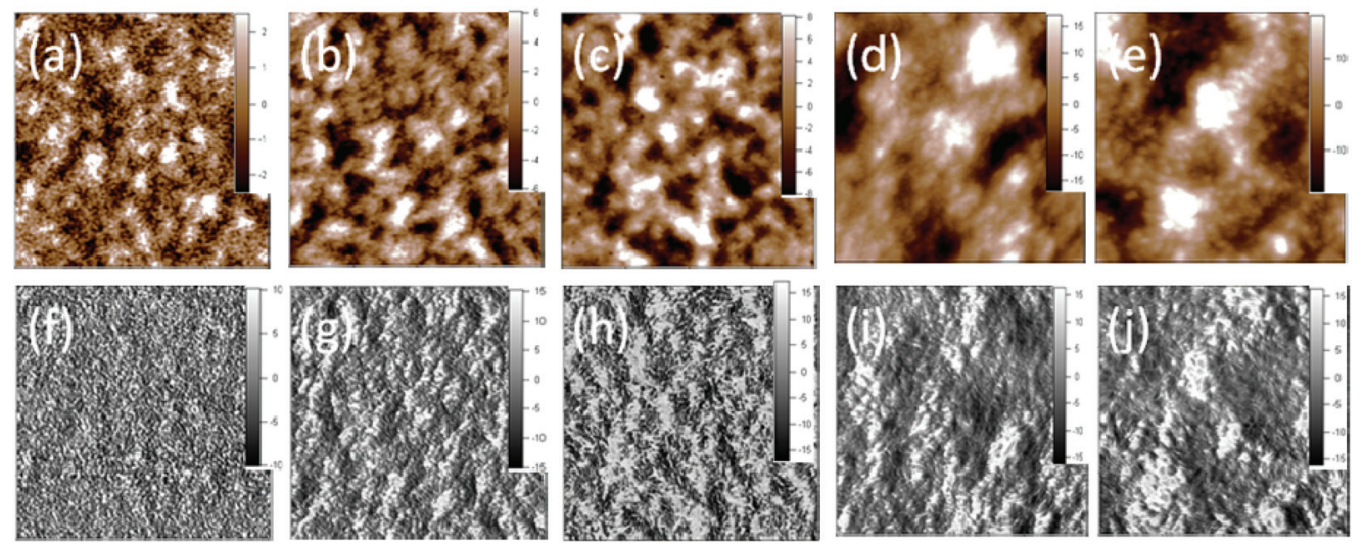

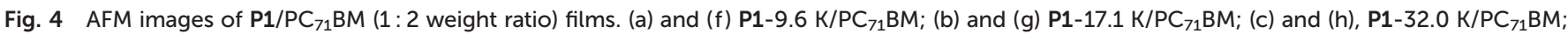
(d) and (i) P1-72.9 K/PC ${ }_{71} \mathrm{BM}$; (e) and (j) P1-138.9 K/PC ${ }_{71} \mathrm{BM}$. (a)-(e) are height images; (f)-(j) are phase images. All images are $2 \times 2 \mu \mathrm{m}$. 
is a finite limit to the benefit of increasing polymer molecular weight on the charge transport properties of the material and BHJ solar cell performance.

\section{Experimental}

Unless noted, all materials were reagent grade and used as received without further purification. The synthesis of monomers 1 and 2 have been reported in literature. ${ }^{31,50}$ All the other starting compounds and reagents are commercially available. Experimental methods and instruments and detailed characterization can be found in the ESI. $\dagger$

\section{General procedure for the polymer synthesis}

The bis(trimethylstannyl) compound 1 (0.15 $\mathrm{mmol})$, the diiodo compound $2(0.15 \mathrm{mmol})$, and the $\mathrm{Pd}$ catalyst (the molar ratios of the respective catalysts were listed in Table 1) were added to a $10 \mathrm{~mL}$ microwave tube under nitrogen. Dry solvent was then added via a syringe and the reaction mixture was purged with nitrogen for $5 \mathrm{~min}$. The reaction tube was then heated to the reaction temperature (Table 1) for polymerization. After the polymerization was finished, a drop of phenyltrimethyl tin was added as end capping reagent and the end capping process took 2 hours. Bromobenzene was then added and the reaction mixture was stirred for another 2 hours. After cooling to room temperature, the polymer was precipitated by addition of $50 \mathrm{~mL}$ methanol, filtered through a Soxhlet thimble. The precipitate was then subjected to Soxhlet extraction with methanol, acetone, hexanes, dichloromethane and chloroform. The polymer was recovered as solid from the chloroform fraction by precipitation from methanol. The solid was dried under vacuum. The molecular weights and yields are listed in Table 1 . The IR and ${ }^{1} \mathrm{H}$ NMR spectra can be found in the ESI. $\dagger$

\section{Fabrication of the BHJ polymer solar cells}

Polymer solar cells were processed on pre-patterned indium tin oxide (ITO) coated glass substrates with a sheet resistance of $15 \Omega$ per square. First a $30 \mathrm{~nm}$ thick layer of $\mathrm{ZnO}$ nanopaticles (average size $\sim 9 \mathrm{~nm}$ ) was deposited on the ultrasonically cleaned ITO substrates. Active layer was deposited by spin coating an $o$ DCB solution containing $10 \mathrm{mg}$ of polymer and $20 \mathrm{mg}$ of phenyl- $\mathrm{C}_{71}$-butyric acid methyl ester $\left(\mathrm{PC}_{71} \mathrm{BM}\right)$. The films were then transferred to a metal evaporation chamber where $\mathrm{MoO}_{3}(10 \mathrm{~nm})$ and $\mathrm{Ag}(100 \mathrm{~nm})$ were deposited through a shadow mask (active area was $0.1 \mathrm{~cm}^{2}$ ) at approximately $1 \times$ $10^{-6}$ torr. Film thickness was determined by Veeco Dektak 150 Surface Profiler. The current density-voltage measurements of the devices were carried out using a $1 \mathrm{~kW}$ Oriel solar simulator with an AM 1.5G filter as the light source in conjunction with a Keithley 2400 source meter. For accurate measurement, the illumination intensity was set to $100 \mathrm{~mW} \mathrm{~cm}^{-2}$ and was calibrated using a reference silicon solar cell (PV measurements Inc.) certified by the National Renewable Energy Laboratory.

\section{Acknowledgements}

This work was made possible by support of the Victorian Organic Solar Cell Consortium, with funding provided by the Victorian State Government Department of Primary Industries (Energy Technology Innovation Strategy), Australian Renewable Energy Agency (ARENA Project 2-A018 and Australian Centre for Advanced Photovoltaics) and the Victorian State Government Department of Business Innovation (Victorian Science Agenda). Dr W. W. H. Wong is supported by an Australian Research Council Future Fellowship (FT130100500).

\section{Notes and references}

1 D. Milstein and J. K. Stille, J. Am. Chem. Soc., 1978, 100, 3636-3638.

2 Z. Bao, W. Chan and L. Yu, Chem. Mater., 1993, 5, 2-3.

3 Z. Bao, W. K. Chan and L. Yu, J. Am. Chem. Soc., 1995, 117, 12426-12435.

4 B. Carsten, F. He, H. J. Son, T. Xu and L. Yu, Chem. Rev., 2011, 111, 1493-1528.

5 U. Asawapirom, R. Güntner, M. Forster, T. Farrell and U. Scherf, Synthesis, 2002, 1136-1142.

6 Y.-J. Cheng, S.-H. Yang and C.-S. Hsu, Chem. Rev., 2009, 109, 5868-5923.

7 K. Okamoto and C. K. Luscombe, Polym. Chem., 2011, 2, 2424-2434.

8 Z. B. Henson, K. Mullen and G. C. Bazan, Nat. Chem., 2012, 4, 699-704.

9 R. C. Coffin, J. Peet, J. Rogers and G. C. Bazan, Nat. Chem., 2009, 1, 657-661.

10 T.-Y. Chu, J. Lu, S. Beaupré, Y. Zhang, J.-R. Pouliot, J. Zhou, A. Najari, M. Leclerc and Y. Tao, Adv. Funct. Mater., 2012, 22, 2345-2351.

11 I. Osaka and R. D. McCullough, Acc. Chem. Res., 2008, 41, 1202-1214.

12 R. J. Kline, M. D. McGehee, E. N. Kadnikova, J. Liu and J. M. J. Fréchet, Adv. Mater., 2003, 15, 1519-1522.

13 L. Huo and J. Hou, Polym. Chem., 2011, 2, 2453-2461.

14 Y. Li, Acc. Chem. Res., 2012, 45, 723-733.

15 M. Wang, X. Hu, P. Liu, W. Li, X. Gong, F. Huang and Y. Cao, J. Am. Chem. Soc., 2011, 133, 9638-9641.

16 X. Zhan and D. Zhu, Polym. Chem., 2010, 1, 409-419.

17 R. S. Kularatne, P. Sista, H. Q. Nguyen, M. P. Bhatt, M. C. Biewer and M. C. Stefan, Macromolecules, 2012, 45, 7855-7862.

18 R. S. Kularatne, F. J. Taenzler, H. D. Magurudeniya, J. Du, J. W. Murphy, E. E. Sheina, B. E. Gnade, M. C. Biewer and M. C. Stefan, J. Mater. Chem. A, 2013, 1, 15535-15543.

19 H. G. Kim, S. B. Jo, C. Shim, J. Lee, J. Shin, E. C. Cho, S.-G. Ihn, Y. S. Choi, Y. Kim and K. Cho, J. Mater. Chem., 2012, 22, 17709-17717.

20 Z. He, C. Zhong, S. Su, M. Xu, H. Wu and Y. Cao, Nat. Photonics, 2012, 6, 591-595. 
21 Y. Zhang, S. K. Hau, H.-L. Yip, Y. Sun, O. Acton and A. K. Y. Jen, Chem. Mater., 2010, 22, 2696-2698.

22 C. Piliego, T. W. Holcombe, J. D. Douglas, C. H. Woo, P. M. Beaujuge and J. M. J. Fréchet, J. Am. Chem. Soc., 2010, 132, 7595-7597.

23 J. Hou, M.-H. Park, S. Zhang, Y. Yao, L.-M. Chen, J.-H. Li and Y. Yang, Macromolecules, 2008, 41, 6012-6018.

24 W. W. H. Wong, J. Subbiah, S. R. Puniredd, W. Pisula, D. J. Jones and A. B. Holmes, Polym. Chem., 2014, 5, 1258-1263.

25 Z. Xiao, J. Subbiah, K. Sun, S. Ji, D. J. Jones, A. B. Holmes and W. W. H. Wong, J. Mater. Chem. C, 2014, 2, 1306-1313.

26 L. Huo, S. Zhang, X. Guo, F. Xu, Y. Li and J. Hou, Angew. Chem., Int. Ed., 2011, 50, 9697-9702.

27 J. Subbiah, B. Purushothaman, M. Chen, T. Qin, M. Gao, D. Vak, F. H. Scholes, X. Chen, S. E. Watkins, G. J. Wilson, A. B. Holmes, W. W. H. Wong and D. J. Jones, Adv. Mater., 2015, 27, 702-705.

28 Y.-X. Xu, C.-C. Chueh, H.-L. Yip, F.-Z. Ding, Y.-X. Li, C.-Z. Li, X. Li, W.-C. Chen and A. K. Y. Jen, Adv. Mater., 2012, 24, 6356-6361.

29 Y. Zhang, S.-C. Chien, K.-S. Chen, H.-L. Yip, Y. Sun, J. A. Davies, F.-C. Chen and A. K. Y. Jen, Chem. Commun., 2011, 47, 11026-11028.

30 N. Wang, Z. Chen, W. Wei and Z. Jiang, J. Am. Chem. Soc., 2013, 135, 17060-17068.

31 H. Zhou, L. Yang, A. C. Stuart, S. C. Price, S. Liu and W. You, Angew. Chem., Int. Ed., 2011, 50, 2995-2998.

32 L. Yang, H. Zhou, S. C. Price and W. You, J. Am. Chem. Soc., 2012, 134, 5432-5435.

33 Z. Li, J. Lu, S.-C. Tse, J. Zhou, X. Du, Y. Tao and J. Ding, J. Mater. Chem., 2011, 21, 3226-3233.

34 J. C. Bijleveld, A. P. Zoombelt, S. G. J. Mathijssen, M. M. Wienk, M. Turbiez, D. M. de Leeuw and R. A. J. Janssen, J. Am. Chem. Soc., 2009, 131, 16616-16617.

35 J. Li, Y. Zhao, H. S. Tan, Y. Guo, C.-A. Di, G. Yu, Y. Liu, M. Lin, S. H. Lim, Y. Zhou, H. Su and B. S. Ong, Sci. Rep., 2012, 2, 754 .
36 V. Farina and G. P. Roth, Advances in Metal-Organic Chemistry, JAI Press, New York, 1996.

37 M. R. Netherton and G. C. Fu, Org. Lett., 2001, 3, 42954298.

38 Z. H. Li, M. S. Wong, Y. Tao and J. Lu, Chem. - Eur. J., 2005, 11, 3285-3293.

39 C. J. Brabec, C. Winder, N. S. Sariciftci, J. C. Hummelen, A. Dhanabalan, P. A. van Hal and R. A. J. Janssen, Adv. Funct. Mater., 2002, 12, 709-712.

40 M. C. Scharber, D. Mühlbacher, M. Koppe, P. Denk, C. Waldauf, A. J. Heeger and C. J. Brabec, Adv. Mater., 2006, 18, 789-794.

41 G. Li, R. Zhu and Y. Yang, Nat. Photonics, 2012, 6, 153-161.

42 L. Dou, C.-C. Chen, K. Yoshimura, K. Ohya, W.-H. Chang, J. Gao, Y. Liu, E. Richard and Y. Yang, Macromolecules, 2013, 46, 3384-3390.

43 I. Osaka, M. Saito, H. Mori, T. Koganezawa and K. Takimiya, Adv. Mater., 2012, 24, 425-430.

44 W. Li, L. Yang, J. R. Tumbleston, L. Yan, H. Ade and W. You, Adv. Mater., 2014, 26, 4456-4462.

45 Y. Liu, J. Zhao, Z. Li, C. Mu, W. Ma, H. Hu, K. Jiang, H. Lin, H. Ade and H. Yan, Nat. Commun., 2014, 5, 5293.

46 X. Zhang, H. Bronstein, A. J. Kronemeijer, J. Smith, Y. Kim, R. J. Kline, L. J. Richter, T. D. Anthopoulos, H. Sirringhaus, K. Song, M. Heeney, W. Zhang, I. McCulloch and D. M. DeLongchamp, Nat. Commun., 2013, 4, 2238.

47 R. Noriega, J. Rivnay, K. Vandewal, F. P. V. Koch, N. Stingelin, P. Smith, M. F. Toney and A. Salleo, Nat. Mater., 2013, 12, 1038-1044.

48 J. Yuan, Z. Zhai, H. Dong, J. Li, Z. Jiang, Y. Li and W. Ma, Adv. Funct. Mater., 2013, 23, 885-892.

49 H. N. Tsao, D. M. Cho, I. Park, M. R. Hansen, A. Mavrinskiy, D. Y. Yoon, R. Graf, W. Pisula, H. W. Spiess and K. Müllen, J. Am. Chem. Soc., 2011, 133, 2605-2612.

50 T. Qin, W. Zajaczkowski, W. Pisula, M. Baumgarten, M. Chen, M. Gao, G. Wilson, C. D. Easton, K. Müllen and S. E. Watkins, J. Am. Chem. Soc., 2014, 136, 6049-6055. 